\title{
GENGIVITE ULCERATIVA NECROSANTE E LEUCOPLASIA PILOSA EM PACIENTE HIV+
}

Thamielem Pereira LIVI, Francielli CARARO, Cassius TORRES-PEREIRA, Cleto Mariosvaldo PIAZZETA, José Miguel AMENÁBAR

A gengivite ulcerativa necrosante (GUN) e a leucoplasia pilosa são lesões bucais fortemente associadas com infecção pelo HIV. Relatamos o caso de um paciente do sexo masculino, 31 anos de idade que foi atendido na Disciplina de Diagnóstico Bucal da UFPR, com queixa de dor gengival, mobilidade dental e ulcerações. Durante o exame clínico o paciente relatou ser portador do vírus HIV há 8 anos, porém, não utilizava medicamentos antiretrovirais. Foram observadas ulcerações na margem gengival e destruição das papilas interdentais na região anterior inferior, com diagnóstico de GUN. Também foi observada leucoplasia pilosa, na borda lateral esquerda da língua. Foi prescrito Metronidazol, Diclofenaco Sódico, ambos por 7 dias, e bochechos com Solução de Peróxido de Hidrogênio e Clorexidina durante 15 dias. Com esta conduta, houve uma regressão da GUN e realizou-se raspagem supra-gengival dos dentes anteriores inferiores e foi solicitado exame de contagem de linfócitos T CD4+ / CD8+ e de quantificação de carga viral de HIV-1. Os resultados mostraram decréscimo na contagem de CD4+ em um comparativo de 6 anos. Concluiu-se que este resultado, provavelmente influenciou o agravamento da GUN e o aparecimento da leucoplasia pilosa, que neste período apresentou um aumento em sua extensão.

Palavras- chave: HIV; Leucoplasia pilosa; Gengivite ulcerativa necrosante 